\title{
Analisis Pelaksanaan Perubahan Hak Guna Bangunan Untuk Rumah Tinggal Yang Dibebani Hak Tanggungan Menjadi Hak Milik
}

\author{
Nur Sofiatun \\ Mahasiswa Program Magister (S2) Kenotariatan Fakultas Hukum Unissula
}

\begin{abstract}
Abstrak
Spesifikasi penelitian ini adalah deskriptif analitis yaitu menggambarkan peraturan perundang-undangan yang berlaku dikaitkan dengan teori-teori hukum dan praktek pelaksanaan hukum positif yang menyangkut permasalahan tersebut. Berdasarkan hasil penelitian diperoleh hasil bahwa pelaksanaan perubahan Hak Guna Bangunan atas tanah untuk rumah tinggal menjadi Hak Milik yang dibebani Hak Tanggungan adalah perubahan dilakukan atas permohonan pemegang hak dengan persetujuan dari pemegang Hak Tanggungan, dengan pernyataan persetujuan tertulis disertai penyerahan sertipikat Hak Tanggungan yang bersangkutan. Akibat hukumnya dengan perubahan Hak Guna Bangunan atas tanah untuk rumah tinggal menjadi Hak Milik yang dibebani Hak Tanggungan adalah dengan perubahan hak tersebut maka hak atas tanahnya hapus menjadi Tanah Negara, dengan hapusnya hak atas tanah yang dibebaninya, maka Hak Tanggungan hapus dengan sendirinya.
\end{abstract}

Kata Kunci : Hak Guna Bangunan, Hak Milik, Hak Tanggungan

\section{A. PENDAHULUAN}

Tanah memiliki peran yang sangat penting, artinya dalam kehidupan bangsa Indonesia ataupun dalam pelaksanaan pembangunan nasional yang diselenggarakan sebagai upaya berkelanjutan untuk mewujudkan masyarakat yang adil dan makmur berdasarkan Pancasila dan Undang-Undang Dasar 1945. Oleh karena itu pengaturan penguasaan, pemilikan dan penggunaan tanah perlu lebih diarahkan bagi semakin terjaminnya tertib di bidang hukum pertanahan, administrasi pertanahan, penggunaan tanah, ataupun pemeliharaan tanah dan lingkungan hidup, sehingga adanya kepastian hukum di bidang pertanahan ${ }^{1}$.

Pasal 8 (UUHT) menentukan bahwa pemberi HaK Tanggungan adalah orang perseorangan atau badan hukum yang mempunyai kewenangan untuk melakukan perbuatan hukum terhadap obyek Hak Tanggungan yang bersangkutan. Pasal 9 (UUHT) menyebutkan bahwa pemegang Hak Tanggungan adalah orang perseorangan atau badan hukum yang berkedudukan sebagai pihak yang berpiutang. Hak Guna Bangunan untuk rumah tinggal yang sedang dibebani Hak Tanggungan dapat dilakukan peningkatan hak menjadi Hak Milik, hal ini diatur melalui Peraturan Menteri Negara Agraria/Kepala Badan Pertanahan Nasional (PMNA/KBPN) Nomor 5 tahun 1998 tentang Perubahan Hak Guna Bangunan atau Hak Pakai atas Tanah Untuk Rumah Tinggal yang dibebani Hak Tanggungan Menjadi Hak Milik. Perubahan tersebut dapat

1 Boedi Harsono, 2007, Hukum Agraria Indonesia, Himpunan Peraturan-Peraturan Hukum Tanah, Djambatan, Jakarta, Hlm. 70. dilakukan atas permohonan pemegang hak dengan persetujuan secara tertulis dari pemegang Hak Tanggungan disertai Sertipikat Hak Tanggungan pada Kantor Pertanahan dimana objek Hak Tanggungan itu berada. Permohonan yang diajukan berfungsi sebagai pelepasan hak atas tanah kepada Negara dan sebagai permohonan Hak Milik.

Permasalahannya adalah bagaimana pelaksanaan perubahan Hak Guna Bangunan atas tanah untuk rumah tinggal yang dibebani Hak Tanggungan menjadi Hak Milik dan akibat hukumnya terhadap kreditor dengan perubahan hak tersebut, apa yang menjadi jaminan bagi kreditor bagi pelunasan utang. Dalam konteks ini peraturan perundang-undangan telah memberikan pengaman kepada kreditor dalam menyalurkan kredit kepada debitor, yakni dengan memberikan jaminan umum menurut Pasal 1131 dan 1132 KUHPerdata yang menentukan bahwa semua harta kekayaan (kebendaan) debitor baik bergerak maupun tidak bergerak, yang sudah ada maupun yang akan ada menjadi jaminan atas seluruh perikatannya dengan kreditor. Apabila terjadi wanprestasi maka seluruh harta benda debitor dijual lelang dan dibagi-bagi menurut besar kecilnya piutang masing-masing kreditor. Namun perlindungan yang berasal dari jaminan umum tersebut dirasakan belum memberikan rasa aman bagi kreditor, sehingga dalam praktik penyaluran kredit, bank memandang perlu untuk meminta jaminan khusus terutama yang bersifat kebendaan.

Berdasarkan latar belakang masalah tersebut di atas penulis mengangkat tesis ini dengan judul "Analisis Pelaksanaan Perubahan Hak Guna Bangunan (HGB) Untuk Rumah Tinggal Yang Dibebani Hak Tanggungan (HT) Menjadi Hak Milik (HM) Di Kota Semarang". 


\section{B. Metode Penelitian}

Metode pendekatan yang digunakan dalam penelitian ini adalah metode yuridis empiris.Data yang dikumpulkan dalam penelitian ini meliputi jenis data primer dan data sekunder. Data primer yang dipakai dalam penelitian ini adalah mengadakan observasi, yaitu melakukan pengamatan secara langsung ke objek penelitian dengan mengamati proses administratif pelaksanaan serta mengadakan wawancara secara struktur, maksudnya menggunakan daftar pertanyaan sebagai pedoman kepada pimpinan perusahaan, khususnya yang menyangkut tentang proses perubahan status.

\section{HASIL DAN PEMBAHASAN}

1. Pelaksanaan Perubahan status Hak Guna Bangunan atas tanah untuk rumah tinggal menjadi Hak Milik yang dibebani Hak Tanggungan

Pelaksanaan permohonan perubahan hak diajukan oleh pemegang hak atau kuasanya kepada Kepala Kantor Pertanahan Kota Semarang dengan formulir yang telah disediakan dan disertai ${ }^{2}$ :

a. Sertipikati Hak Guna Bangunan yang telah dicek keabsahannya.

b. Sertipikat Hak Tanggungan yang bersangkutan.

c. Fotocopy Ijin Mendirikan Bangunan, yang mencantumkan bahwa bangunan tersebut digunakan untuk rumah tinggal atau surat keterangan dari Kepala Desa/Lurah jika Ijin Mendirikan Bangunan tersebut belum dikeluarkan oleh instansi yang berwenang.

d. Fotocopy SPPT-PBB tahun terakhir.

e. Pernyataan dari pemohon bahwa dengan perolehan Hak Milik yang dimohon pendaftarannya itu yang bersangkutan akan mempunyai Hak Milik atas tanah untuk rumah tinggal tidak lebih dari 5 (lima) bidang yang seluruhnya meliputi luas tidak lebih dari 5000 $\mathrm{M}^{2}$.

f. Surat persetujuan dari kreditor tentang persetujuan kepada debitor mengenai dilepaskannya Hak Guna Bangunan yang bersangkutan untuk diubah menjadi Hak Milik.

g. Fotocopy identitas pemohon dan kuasanya

h. Surat Kuasa dari pemohon kepada PPAT.

i. Membayar tarif Penerimaan Negara Bukan Pajak Pendaftaran Perubahan Hak dari Hak Guna Bangunan menjadi Hak Milik berdasarkan PP. Nomor 13 Tahun 2010, sebesar Rp. 50.000 (lima puluh ribu rupiah).

\footnotetext{
2 Sujarno, Wawancara, Ka Subsi Pendaftaran Hak, Kantor Pertanahan Kota Semarang
}

j. Membayar tarif Penerimaan Negara Bukan Pajak Pelayanan Pendaftaran Hapusnya Hak Tanggungan berdasarkan Peraturan Pemerintah Nomor 13 Tahun 2010, sebesar Rp. 50.000 (lima puluh ribu rupiah).

Pemohon atau kuasanya mengajukan permohonan perubahan Hak Guna Bangunan atas tanah untuk rumah tinggal yang sedang dibebani Hak Tanggungan menjadi Hak Milik pada Kantor Pertanahan Kota Semarang dengan membawa semua persyaratan sebagaimana tersebut diatas. Pemohon menyerahkan permohonan tersebut pada petugas di loket 6 , petugas loket 6 memeriksa kelengkapan permohonan tersebut, apabila tidak lengkap dikembalikan kepada pemohon atau kuasanya untuk dilengkapi dan apabila lengkap maka diteruskan kepada Kepala Sub Seksi Pendaftaran Hak untuk diperiksa, selanjutnya berkas permohonan dikembalikan ke loket 6 untuk didaftar, dibuatkan surat perintah setor dan tanda terima pendaftaran, pemohon diberikan surat perintah setor dan selanjutnya membayar biaya pendaftaran pada loket 11 sesuai dengan nilai yang tercantum pada surat perintah setor tersebut, oleh petugas loket 11 diberikan kwitansi pembayaran, kwitansi pembayaran tersebut oleh pemohon diserahkan ke loket 6 dan oleh petugas loket 6 diberikan tanda terima pendaftarannya, selanjutnya berkas permohonan diteruskan kepada petugas pengolahan data, dicatat hapusnya Hak Guna Bangunan dan hapusnya Hak Tanggungan yang bersangkutan dalam buku tanah dan sertipikatnya serta daftar umum lainnya serta mencatat Hak Milik atas tanah bekas Hak Guna Bangunan tersebut dengan menyebutkan keputusan yang menjadi dasar adanya Hak Milik tersebut.

Berkas permohonan tersebut kemudian diteruskan kepada Kepala Sub Seksi Pendaftaran Hak untuk diteliti kembali dan apabila memenuhi syarat maka pada buku tanah dan sertipikatnya dibubuhi paraf selanjutnya diteruskan kepada Kepala Seksi Hak Tanah dan Pendaftaran Tanah untuk diteliti dan apabila memenuhi syarat maka buku tanah dan sertipikat tersebut di tandatangani, selanjutnya berkas permohonan tersebut dikembalikan kepada petugas pengolahan data untuk distempel/cap kantor kemudian dikirim ke loket 10 dan diserahkan kepada pemohon atau kuasanya ${ }^{3}$.

\section{Akibat Hukum Perubahan Status Hak Guna Bangunan atas tanah untuk rumah tinggal menjadi Hak Milik yang dibebani Hak Tanggungan}

\footnotetext{
3 Usman, Wawancara, Staf Subsi Pendaftaran
} Hak, Kantor Pertanahan Kota Semarang 
Berdasarkan Keputusan Meteri Negara/Badan Pertanahan Nasional Nomor 6 Tahun 1998 tentang Pemberian Hak Milik atas tanah untuk rumah tinggal mengakibatkan hapusnya hak atas tanah dan menjadi tanah Negara, karena permohonan perubahan Hak Guna Bangunan atas tanah untuk rumah tinggal menjadi Hak milik berlaku juga sebagai pernyataan pelepasan hak atas tanah kepada Negara sehingga haknya hapus dan menjad Tanah Negara. Hapusnya hak atas tanah tersebut mengakibatkan gugurnya Hak Tanggungan yang membebaninya, oleh karena itu para kreditor pemegang Hak Tanggugan keberatan akan diubahnya Hak Guna Bangunan yang menjadi jaminan pelunasan hutang debitor menjadi Hak Milik.

Untuk memberikan kepastian hukum mengenai jaminan pelunasan kredit yang diberikan, maka diberikan jalan keluar oleh Pemerintah yaitu Peraturan Menteri Negara Agraria/Badan Pertanahan Nasional Nomor Tahun 1998 tentang Perubahan Hak Guna Bangunan atau Hak Pakai atas tanah untuk rumah tinggal yang dibebani Hak Tanggungan menjadi Hak Milik.

Berdasarkan hasil penelitian di Kantor Pertanahan Kota Semarang sebelum dilakukan permohonan perubahan status Hak Guna Bangunan atas tanah untuk rumah tinggal yang dibebani Hak Tanggungan menjadi Hak Milik untuk menjamin pelunasan hutang debitor kepada kreditor pemegang Hak Tanggungan, maka antara pemegang hak atas tanah dengan pemegang Hak Tanggungan membuat Surat Kuasa Membebankan Hak Tanggungan (SKMHT) atas Hak Milik yang diperolehnya sebelum hak itu di daftar, di Kantor Pertanahan Kota Semarang. Pembuatan SKMHT tersebut dilakukan dihadapan PPAT atau Notaris yang berwenang dengan disertai janji bahwa apabila Hak Guna Bangunan yang menjadi objek jaminan ini diubah menjadi Hak Milik, maka tidak mengakibatkan hapunya atau batalnya akta ini. SKMHT Yang telah dibuat oleh pemegang hak dan pemegang Hak Tanggungan digunakan sebagai dasar pembuatan Akta Pemberian Hak Tanggungan setelah Hak Milik tersebut didaftar apabila pemberi Hak Tanggungan tidak dapat hadir.

Pemegang hak tersebut tidak perlu memohon hak yang baru, yaitu Hak Milik atas tanah yang di lepaskan kepada Negara, karena permohonan perubahan Hak Guna Bangunan atas rumah tinggal yang sedang dibebani Hak Tanggungan menjadi Hak Milik selain sebagai pernyataan pelepasan hak juga sebagai permohonan hak yang baru yaitu Hak Milik.

Pendapat penulis berdasarkan kajian hal-hal di atas bahwa akibat hukum yang timbul atas perubahan status Hak Guna Bangunan atas tanah untuk rumah tinggal yang dibebani Hak
Tanggungan menjadi Hak Milik adalah menjadi hapusnya Hak Guna Bangunan tersebut menjadi Tanah Negara. Dengan demikian Hak Tanggungan yang membebaninya gugur dengan sendirinya. Oleh karena itu untuk menjamin kelangsungan pelunasan hutang debitor kepada kreditor sebelum hak itu di daftar perlu dibuatkan SKMHT antara pemegang hak dengan pemegang Hak Tanggungan di hadapan Notaris atau PPAT sebadai dasar pembuatan APHT.

Kepastian hak atas tanah untuk rumah tinggal yang luasnya $600 \mathrm{~m} 2$ atau kurang dengan status Hak Guna Bangunan yang dibebani Hak Tanggungan seyogyanya diubah statusnya menjadi Hak Milik, yang merupakan pelaksanaan kebijakan Pemerintah dalam memberi kepastian kelangsungan hak atas tanah untuk rumah tinggal bagi perseorangan Warga Negara Indonesia, yang jumlahnya meliputi jutaan bidang. Kantor Pertanahan Kota Semarang dalam melaksanakan pelayanan pendaftaran perubahan Hak Guna Bangunan yang dibebani Hak Tanggungan menjadi Hak Milik sudah sesuai dengan prosedur dan peraturan perundang-undangan yang berlaku.

\section{PENUTUP}

\section{Simpulan}

a. Pelaksanaan perubahan Hak Guna Bangunan atas tanah untuk rumah tinggal menjadi Hak Milik yang dibebani Hak Tanggungan adalah perubahan dilakukan atas permohonan pemegang hak dengan persetujuan dari pemegang Hak Tanggungan, dengan pernyataan persetujuan tertulis disertai penyerahan sertipikat Hak Tanggungan yang bersangkutan. Permohonan perubahan hak yang diajukan oleh pemegang hak tersebut berlaku sebagai pernyataan pelepasan Hak Guna Bangunan dan persetujuan dari pemegang Hak Tanggungan juga berlaku sebagai persetujuan pelepasan Hak Guna Bangunan dengan ketentuan bahwa tanah tersebut diberikan kembali kepada bekas pemegang hak dengan Hak Milik. Permohonan perubahan tersebut mengakibatkan hapusnya hak atas tanah dan menjadi tanah negara, dengan demikian Hak Tanggungan yang membebani Hak Guna Bangunan tersebut juga gugur dengan hapusnya Hak Guna Bangunan tersebut.

b. Akibat hukumnya dengan perubahan Hak Guna Bangunan atas tanah untuk rumah tinggal menjadi Hak Milik yang dibebani Hak Tanggungan adalah dengan perubahan hak tersebut maka hak atas tanahnya hapus menjadi Tanah Negara, dengan hapunya hak atas tanah yang dibebaninya, maka Hak Tanggungan 
hapus dengan sendirinya (Pasal 18 ayat (1) huruf d Undang-Undang Hak Tanggungan). Dengan demikian Hak Tanggungan yang membebani Hak Guna Bangunan tersebut juga gugur dengan hapusnya Hak Guna Bangunan itu menjadi Hak Milik. Untuk memberi kepastian hukum kepada kreditor pemegang Hak Tanggungan akan kelangsungan jaminan pelunasan kreditnya, maka sebelum dilakukan perubahan Hak Guna Bangunan atas tanah untuk rumah tinggal yang dibebani Hak Tanggungan menjadi Hak Milik dibuatkan Surat Kuasa Membebankan Hak Tanggungan (SKMHT) antara pemegang hak dengan pemegang Hak Tanggungan dihadapan Notaris atau PPAT yang berwenang dengan disertai janji pada SKMHT bahwa apabila Hak Guna Bangunan yang menjadi objek jaminan ini diubah menjadi Hak Milik maka tidak mengakibatkan hapunya atau batalnya akta ini, dengan demikian SKMHT tersebut dapat digunakan sebagai dasar pembuatan Akta Pemberian Hak Tanggungan (APHT) setelah Hak Milik tersebut didaftar di Kantor Pertanahan Kota Semarang.

\section{Saran}

1. Banyak masyarakat merasa kepengurusan perubahan Hak Guna Bangunan atas tanah untuk rumah tinggal menjadi Hak Milik yang dibebani Hak Tanggungan cukup rumit dan membutuhkan birokrasi berbelit, sehingga Kantor Pertanahan Kota Semarang sebaiknya berusaha untuk memperpendek birokrasi dan memudahkan kepengurusan perubahan Hak Guna Bangunan atas tanah untuk rumah tinggal menjadi Hak Milik yang dibebani Hak Tanggungan.

2. Terkait dengan akibat hukum perubahan Hak Guna Bangunan atas tanah untuk rumah tinggal menjadi Hak Milik yang dibebani Hak Tanggungan, perubahan tersebut akan memberikan kepastian hukum kepada pemegang hak atas tanah yang bersangkutan juga untuk kepentingan Kantor Pertanahan, yang merupakan pelaksanaan kebijaksanaan Pemerintah dalam memberi kepastian kelangsungan hak atas tanah untuk rumah tinggal bagi perseorangan Warga Negara Indonesia. Sehingga Kantor Pertanahan Kota Semarang sebaiknya mengadakan sosialisasi dan penyuluhan kepada masyarakat tentang perubahan Hak Guna Bangunan atas tanah untuk rumah tinggal menjadi Hak Milik yang dibebani Hak Tanggungan.

\section{DAFTAR PUSTAKA}

Badrulzaman, Mariam Darus, Perjanjian Kredit Bank, Alumni, Bandung, 1998.

Harsono, Boedi, Hukum Agraria Indonesia, Himpunan Peraturan-Peraturan Hukum Tanah, Djambatan, Jakarta, 2007.

Harsono, Boedi, Sejarah Pembentukan UndangUndang Pokok Agraria Isi dan Pelaksanaannya, Djambatan, Jakarta, 2007.

Lubis, Muhammad Yamin dan Abdul Rahim Lubis, Hukum Pendaftaran Tanah, Mandar Maju, Bandung, 2008.

Patrik, Purwahit dan Kashadi, Hukum Jaminan edisi Revisi dengan UUHT, Fakultas Hukum Undip Semarang, 2008.

Soekanto, Soerjono, Pengantar Penelitian Hukum, UI Press, Jakarta, 1982.

Soeroso, R, Perbandingan Hukum Perdata, Sinar Grafika, Jakarta, 2007.

Sofwan, Sri Soedewi Masjchoen, Hukum Jaminan Di Indonesia Pokok-Pokok Hukum Jaminan Dan Jaminan Perorangan, Liberty, Yogyakarta, 1980.

Sutedi, Adrian, 2007, Peralihan Hak Atas Tanah dan Pendaftarannya, Sinar Grafika, Jakarta.

Usman, Ruchmadi, Pasal-Pasal Tentang Hak Tanggungan Atas Tanah, Djambatan, Jakarta, 1999.

Wantjik, Saleh K., Hak Anda Atas Tanah, Ghalia Indonesia, Jakarta, 1992.

Zein, Ramli. Hak Pengelolaan Dalam Sistem UUPA, Rineka CIpta, 1994. 